Library, E-01 Admin. Bldg.

DEC 91970

\title{
Development
}

\section{and Current Status of the} Standard Nuclear Instrument Module (NIM) System

U.S. EPARTMENT OF COMMERCE

National Bureau of landards 



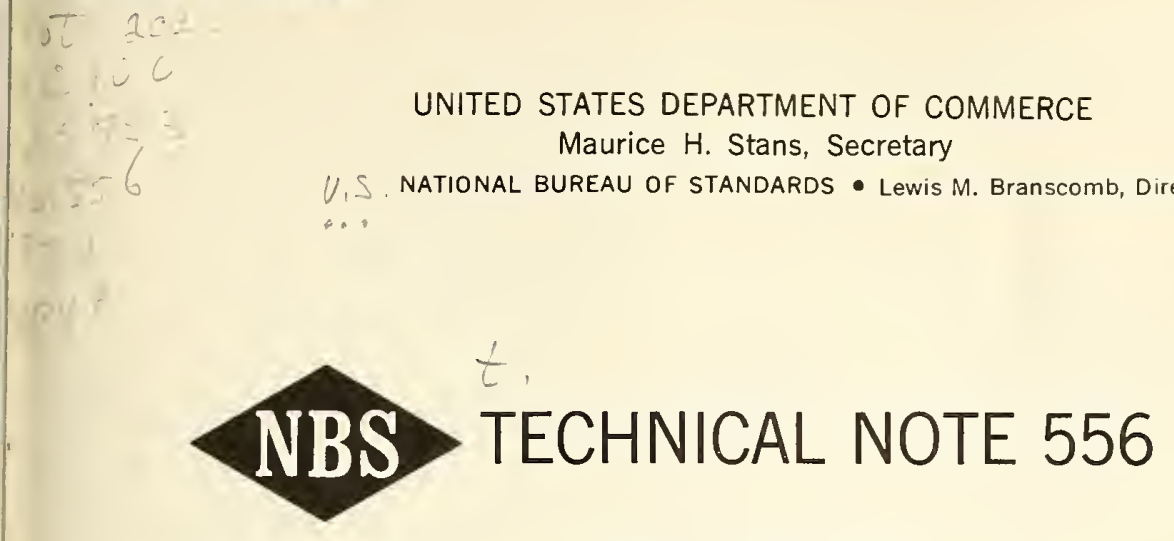

\author{
ISSUED OCTOBER 1970
}

Nat. Bur. Stand. (U.S.), Tech. Note 556, 15 pages (Oct. 1970) CODEN: NBTNA

\title{
Development and Current Status of the Standard Nuclear Instrument Module (NIM) System
}

\author{
Louis Costrell \\ Center for Radiation Research \\ National Bureau of Standards \\ Washington, D.C. 20234
}

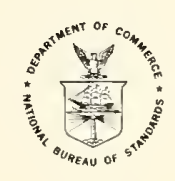

NBS Technical Notes are designed to supplement the Bureau's regular publications program. They provide a means for making available scientific data that are of transient or limited interest. Technical Notes may be listed or referred to in the open literature.

For sale by the Superintendent of Documents, U.S. Government Printing Office, Washington, D.C., 20402.

(Order by SD Catalog No. C 13.46:556). Price 30 cents 



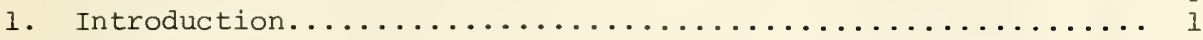

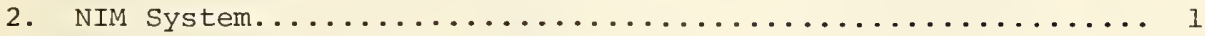

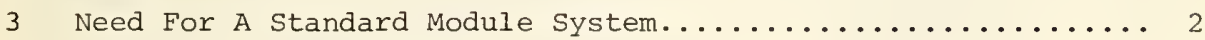

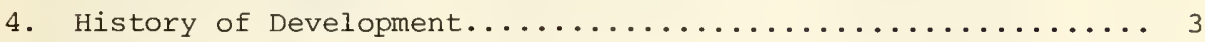

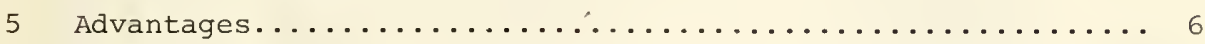

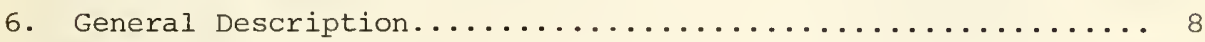

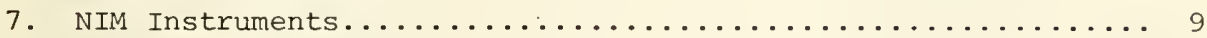

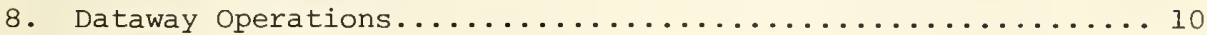

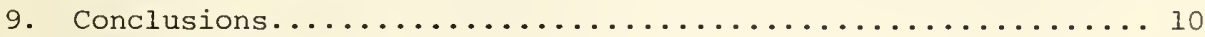

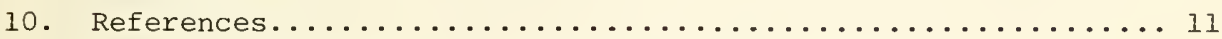

Appendix - Representatives on AEC Comittee on Nuclear.........12 Instrument Modules (NIM Committee)

\section{TABLES AND ILLUSTRATIONS}

Table 1 AEC Committee on Nuclear Instrument Modules......... 4 (NIM Committee)

Fig. 1 NIM System Bin with Modules From a Number of........ iv Laboratories and Manufacturers

Fig. 2 Estimate of NIM Nuclear Instrument Production in U. S.. 5 as a Percentage of Total Modular Nuclear Instrument production in $U$. $S$. 

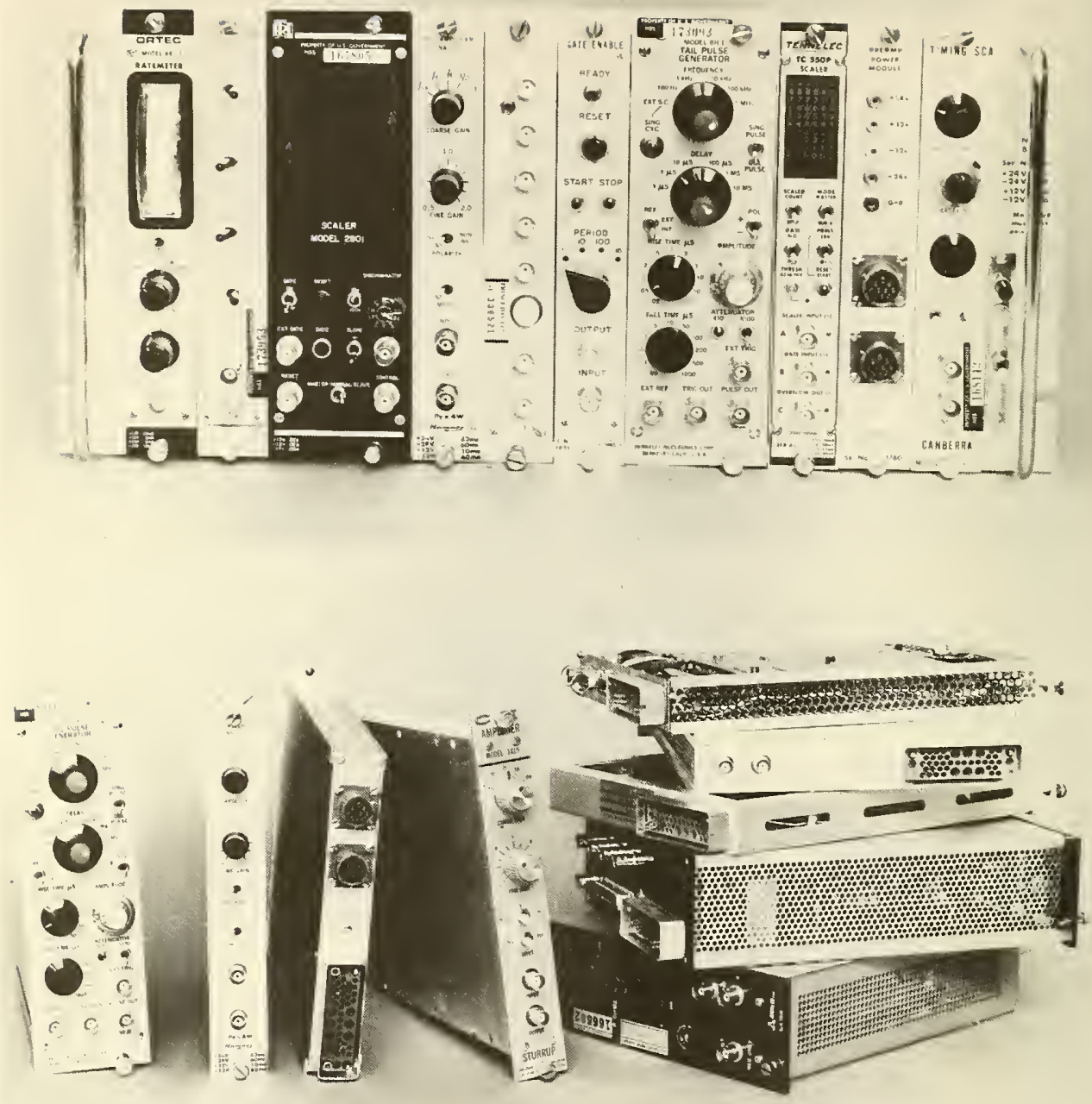

Fig. I NIM System Bin with Modules From a Number of Laboratories and Manufacturers 


\section{Development and Current status \\ of the}

Standard Nuclear Instrument Module (NIM) System

\section{Louis Costrell}

The standard Nuclear Instrument Module (NIM) system described in AEC Report TID-20893 is widely used in laboratories throughout the world. This report presents a history of the development and reviews the current status of the NIM system.

Key words: Instrumentation, Instruments, Modules, Nuclear, Standards, NIM

\section{Introduction}

A 1968 report of the National Academy of Sciences National Research Council ${ }^{1}$ states that "...the Nuclear Instrument Module (NIM) system has revolutionized the manner in which experiments are now performed in nuclear physics." The world-wide impact of the NIM system makes desirable a presentation of the history of its development and a review and summary of its current status.

\section{NIM System}

The NIM system (Fig. 1) is a standardized nuclear instrument module system that provides a degree of instrument interchangeability that is unique in the history of instrumentation. The system consists of NIM modules and bins that conform to specifications of the NIM system ${ }^{2}$. The NIM bins are enclosures, based on standard 19-inch panels 3,4 , that accommodate a multiplicity of NIM modules and provide power at the proper voltages to the modules that are inserted in the bins. Thus, instrumentation systems consisting of NIM bins and modules have a very high degree of flexibility in that the modules of different manufacturers can be readily interchanged. The systems can be efficiently maintained by rapid replacement of defective modules and can be quickly and economically updated by selective replacement of modules by modules of more advanced design. This obviates the necessity of replacing complex and expensive multi-function instruments. Because of the significant advantages of the NIM system, it is now in wide use in laboratories on every continent. 


\section{Need for a Standard Module System}

Early nuclear instruments were self contained entities as was the case with practically all electronic instruments prior to the advent of the transistor. The vacuum tube circuits were mounted on conventional chassis and had conventional 19-inch front panels that were secured in standard cabinets or racks. The instruments had self-contained dc power supplies that were operated from the ac power lines. There was essentially no difficulty with interchangeability. Each instrument was simply inserted in the rack or cabinet and the line cord connected to the power line. To be sure, there were differences in input requirements and output levels. However, there was no appreciable problem of mechanical compatability and, since each instrument contained its own dc supply, electrical power compatability problems were non-existent. The development of the transistor changed all this.

In 1948 Bardeen and Brattain of the Bcll Telephone Laboratories first announced the point contact transistor ${ }^{5}$ and this was followed a few years later by the development of the junction transistor. Though transistors are extremely small compared to vacuum tubes and consume far less power, transistorized instruments that emerged in the 1950's were nonethe-less constructed in a manner quite similar to that of their vacuum tube predecessors. Thus the instruments utilized 19-inch front panels and contained their own dc power supplies operated from the ac line. It rapidly became apparent that such construction was quite uneconomical and inefficient, that a number of transistorized instruments in modular form could be accommodated in the space occupied by a single 19-inch panel, and that a single dc power supply could provide the necessary power to such a multiplicity of instruments.

Many modular instrumentation systems were produced in laboratories and industries throughout the world and, though the savings in space and power were very great indeed, the interchangeability that existed earlier was sacrificed. Interchange of instruments within an assembly of instruments was severely limited. Modules of a given manufacturer or laboratory required bins from the same manufacturer or laboratory and, even with this restriction, interchange was not always possible. A laboratory 
was therefore faced with the necessity of (1) obtaining a variety of noncompatible bins, many of which contained far fewer instruments than they could accommodate, or (2) assembling non-optimized systems, restricting the modules used to those of a single manufacturer so as to avoid the expense of many under-utilized bins. Usually the laboratories struck a compromise between these two unsatisfactory alternatives:

The United Kingdom Atomic Energy Research Establishment at Harwell and the European Organization for Nuclear Research (CERN) at Geneva, Switzerland were among the first laboratories to develop comprehensive modular systems ${ }^{6,7}$. These two systems were pioneer systems, immensely far sighted and extremely useful to the originating laboratories. Later the ESONE Committee of EURATOM began work on an additional modular system known as the ESONE standard ${ }^{8}$. There was also a proliferation of commercial module systems with at least eight nuclear instrument manufacturers in the United States alone producing proprietary systems. Exchange of instruments among laboratories was severely restricted since the bins of one laboratory would not, in general, accommodate the modular instruments of another laboratory and commercially produced instruments could not be intermixed with laboratory constructed instruments or instruments of other manufacturers. That was the situation that developed in the early 1960's. The lack of a widely accepted standard modular system made for extreme inflexibility and represented a serious shortcoming of the nuclear instrumentation field.

\section{History of Development}

In December 1963 the National Bureau of Standards, in a report to the U. S. Atomic Energy Commission, urged:

"......that a module be developed by the National Laboratories with the intent that the module will become standard in all of the National Laboratories and will be duplicated by many manufacturers."

Based on this recommendation, the Division of Biology and Medicine of the U. S. Atomic Energy Commission convened a meeting of representatives of the AEC National Laboratories on February 1964 to determine the interest 
of the laboratories in such a development.* At this meeting it was decided that such a standard module system should be produced and the NIM Committee (AEC Committee on Nuclear Instrument Modules) was established and was assigned responsibility for this task. The Committee included representatives of all of the AEC National Laboratories and other laboratories as listed in Table I with personnel as listed in the appendix. The Committee was enthusiastically supported in this effort by the Atomic Energy Commission.

\section{TABLE I}

\section{AEC COMMITTEE ON NUCLEAR INSTRUMENT MODULES (NIM COMMITTEE)}

U. S. Atomic Energy Commission

Argonne National Laboratory

Battelle Northwest (Formerly Hanford Laboratories)

Brookhaven National Laboratory

Columbia University

Lawrence Radiation Laboratory (Berkeley)

Lawrence Radiation Laboratory (Livermore)

Los Alamos Scientific Laboratory

National Bureau of Standards

Oak Ridge National Laboratory

U. S. AEC Health and Safety Laboratory

Stanford Linear Accelerator Center (Beginning October 1964)

Princeton-Pennsylvania Accelerator (Beginning January 1965)

National Aeronautics \& Space Administration, GSFC

(Beginning January 1965)

Atomic Energy of Canada Limited (Beginning November 1966)

CERN, European Organization for Nuclear Research)

(Beginning November 1966)

Yale University (Beginning February 1968)

National Accelerator Laboratory (Beginning October 1968)

The NIM Committee held its initial meeting on March 17, 1964 and held additional meetings in April and May. Existing module systems were studied so as to take advantage of prior experience. During the development, prototype bins and modules were produced by the Oak Ridge National Laboratory, the Lawrence Radiation Laboratory at Berkeley and the Lawrence *Organizing Committee: F. S. Goulding, LRL/Berkeley; R. J. Berte, AEC; C. J. Borkowski, ORNL; D. B. Brown, Hanford; M. E. Cassidy, AEC/HASL; L. Costrell, NBS; R. J. Darneal, AEC; R. T. Graveson, AEC/HASL; R. Hiebert, LASL; W. A. Higinbotham, BNL; R. C. Kaifer, LRL/Livermore; N. A. Lindsay, LASL; A. E. Larsh, Jr., LRL/Berkeley; D. A. Mack, LRL/Berkeley; C. Sewell, LRL/Livermore; M. G. Strauss, ANL; H. R. Wasson, AEC. 
Radiation Laboratory at Livermore. Later the Berkeley and Livermore laboratories merged their efforts to produce a common design. The prototypes were critically examined at each of the meetings and were important elements in finalizing the specifications. All of the basic decisions were made during the March, April and May meetings. Details remaining to be resolved were cleared up by the NIM Executive Committee (L. Costrell, U. S. National Bureau of Standards, D. A. Mack, Lawrence Radiation Laboratory at Berkeley and G. A. Holt, Oak Ridge National Laboratory. Later T. F. Droege, Princeton-Pennsylvania Accelerator and S. Rankowitz, Brookhaven National Laboratory were added to the Executive Committee.) In July 1964 the specifications for the NIM system were published. 9

Implementation of the NIM standard was amazingly rapid with many laboratories having NIM systems in operation before the end of 1964 . The first commercial NIM instruments were produced in November 1964 and in 1965 a wide variety of NIM instruments was commercially available. By December 1965, a gestation period of less than nine months from the time the NIM Committee first convened, an estimated $30 \%$ to $60 \%$ of the modular nuclear instruments produced in the United states were NIM instruments as shown in Figure 2. Within an additional year this had climbed to between

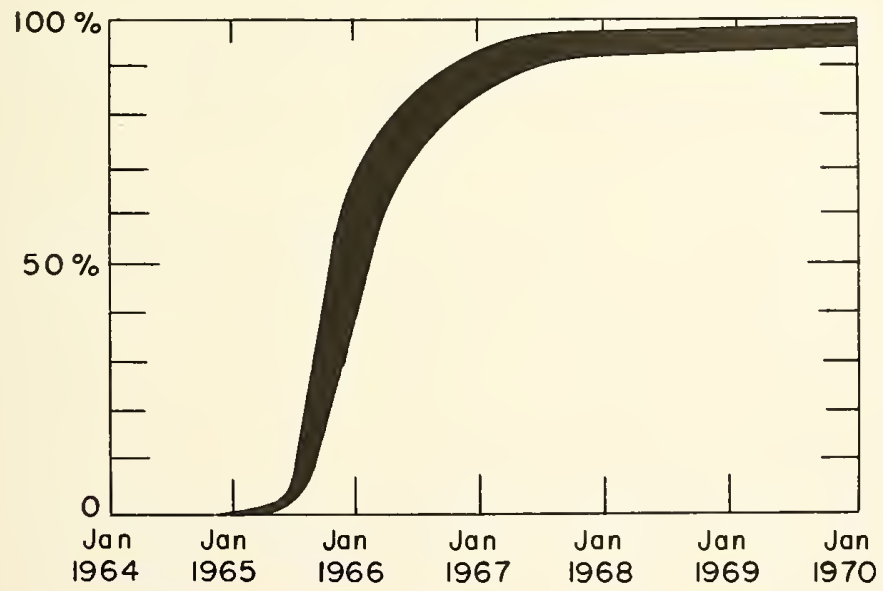

Fig. 2 Estimate of NIM Nuclear Instrument Production in U. S. as a Percentage of Total Modular Nuclear Instrument Production in U. S. 
$80 \%$ and $90 \%$. These instruments became widely used throughout much of the world and European and Asiatic manufacturers began producing instruments in accordance with the NIM specifications. It is estimated that since 1967 in excess of 95\% of the modular nuclear instruments produced in the United States have been NIM instruments and such instruments are produced in considerable numbers in Europe and Asia. An incomplete list of countries producing NIM instruments includes the United States, Australia, Belgium, Canada; England, France, Germany, Israel, Italy, Japan, Norway, Scotland, Sweden, and Switzerland. The NIM standard has received international recognition through its wide acceptance and production in many countries of the world.

It is difficult to recall any other instrumentation system in any field that has received even a reasonable fraction of the broad acceptance and utilization received by the NIM system. It is apparent that the system must provide considerable benefits to command such a following.

\section{Advantages}

The advantages of the NIM system that have accounted for its essentially universal acceptance are many and include the following:

1. Flexibility in interchanging instruments

2. Ready optimization of instrumentation systems

3. Ease of restructuring instrumentation systems

4. Reduction of inventories

5. Increased utilization

6. Ready interchange of instruments between laboratories

7. Deferred obsolescence - update capacity

8. Ease of serviceability

9. Reduction of down time

10. Availability of blank modules

11. Reduction of design effort

12. Availability of numerous commercial NIM instruments from many suppliers.

The advantages listed above derive from the interchangeability of the instruments, the unit function tendency in modular construction, the wide availability of a family of NIM instruments and the wide acceptance 
of the NIM system. The flexibility in interchanging instruments meeting common mechanical and electrical specifications needs no further comment. Economical optimization of instrumentation systems results from the ability to combine instruments from numerous manufacturers. Such optimization was both expensive and inefficient when the modules of one manufacturer could be used only in bins of the same manufacturer. The NIM system interchangeability has drastically altered this situation. For example, any of the hundreds of laboratories using NIM systems can readily combine in a single bin an amplifier from one supplier with a discriminator from a second supplier, a scaler from a third, a high voltage supply from a fourth, and so on. The user thus defines the optimum to suit his fancy and has no difficulty in assembling an optimized system.

The interchangeability also makes it possible to readily restructure instrumentation systems by interchanging instruments as desired. This permits operation with inventories that are considerably reduced over what would be possible with instruments lacking such interchangeability capabilities. The ease with which the same instruments can be used in different instrumentation set-ups also makes for considerably increased utilization. This also encourages interchange of instruments between different laboratories and between sections of the same laboratories.

The "unit function" or limited function construction that is common with modular instruments permits updating of systems by replacing only the specific modules that become outdated. This is considerably facilitated by the interchangeability features of the NIM system.

A variety of instrumentation systems is readily constructed from an inventory consisting of a limited variety of modules. Defective modules are readily replaced so that serviceability is enhanced and down time is drastically reduced. The maintenance of continuity of operation with minimum interruption is especially important in laboratories with expensive capital facilities where highly skilled scientists are delayed in the conduct of their experiments. This is of even greater importance in process control and control of nuclear reactors and other operations where interruptions must be held to an absolute minimum.

Economical blank modules into which circuits can be installed are available from a variety of sources. The mechanical design effort is 
thus drastically reduced and the designer is able to devote his efforts to innovative circuit design. This economy of design effort has been an important and significant benefit to both commercial manufacturers and laboratories constructing special in-house circuits.

The availability of numerous commercial NIM instruments from many suppliers enhances the value of NIM and this in turn encourages manufacturers to produce NIM instruments or to expand their lines of NIM instruments. So the regenerative condition is operative wherein availability produces utility which in turn encourages greater availability which in turn makes for increased utility. This cycle has been an important factor in the growth and the contributions of the NIM system.

\section{General Description}

Compatability of instruments involves three factors:

Mechanical compatability

Electrical compatability from a power supply standpoint

Electrical compatability from a signal standpoint

With regard to NIM, mechanical interchangeability means that any NIM module will fit mechanically into any NIM bin. Electrical interchangeability from a power supply standpoint means that any NIM module when inserted into any NIM bin will connect to the necessary power supply voltages. The objective of the NIM standard was to obtain mechanical and electrical power supply interchangeability and to encourage a considerable degree of electrical signal compatability. This has been achieved to a very great extent.

The NIM specifications are concerned with the mechanical dimensions necessary to assure accommodation of NIM modules by NIM bins, with the connector pair by means of which the module mates with the bin, with the voltages that must be available at the connector and with other items necessary to assure module-bin compatability. Thus the principal concern has been with the mechanical and electrical module-bin interface. In addition, the standard has provided guidance with "typical" power supply specifications, with "preferred" logic levels and with a few other items. The NIM specifications are not concerned with circuit design details, materials or methods of construction. 
Complete families of nuclear instruments in the NIM system are available from many manufacturers. Figure 1 shows a typical NIM bin and a number of NIM modules from a variety of sources. NIM instruments include amplifiers, scalers, coincidence and gating circuits, fanouts, trigger circuits, pile-up gates, pulsers, baseline restorers, pulse stretchers, crossover pickoffs, time pickoffs, ratemeters, current digitizers, analog to digital converters, high voltage supplies, printout controls, particle identifiers and a host of other instruments. In addition, complete pulse height analyzers are available in the NIM system. This permits exchange or expansion of the memories, interchange of the analog to digital converters to provide different functions or different numbers of channels, etc.

Most NIM instrumentation commercially produced is considered nuclear instrumentation and is used primarily in nuclear and high energy physics, nuclear chemistry and other disciplines concerned with radiation measurements. However, many of these instruments, pulse amplifiers, pulse generators, analog to digital converters, pulse height to time converters, high voltage supplies, etc., are also applicable to and used in other areas. Additionally, some NIM instruments are produced for general physics use, for process control and for many other applications. One example of a non-nuclear NIM instrument is a narrow band "lock-in" amplifier used for measurement of extremely low signal intensities in the presence of noise and that finds application in electron resonance, plasma studies, biomedical investigations, laser studies, mass spectrometry, infra red studies, optical pumping, etc. Other non-nuclear NIM instruments include D.C. photometers, photometric preamplifiers, operational amplifiers, light choppers, well logging instruments and a wide variety of other instruments. Numerous control circuits for use with accelerators and accelerator peripherals, as well as many special instruments, are installed in NIM packages in many laboratories.

As mentioned above, a considerable number of instruments intended primarily for the nuclear physics field, such as scalers and analog to digital converters, are finding increased use in a variety of fields, 
including many branches of physics and chemistry as well as in scientific and engineering measurement and control applications. The NIM design has found its widest use in the nuclear area for historical reasons and because of the close cooperation that exists within the nuclear instrumentation community. The extension of NIM instrumentation into non-nuclear areas has been greatest in those disciplines that have appreciable contact with and familiarity with the nuclear field.

\section{Dataway Operations}

Instrumentation systems that receive instructions and communicate data primarily through a dataway (digital bus) structure and utilize a minimum of local controls and readouts are coming into increasing use. Though NIM is used in some instances for such purposes, it was not conceived as a dataway system and does not basically make provision for dataway type operations. The NIM Committee has maintained close contact with the ESONE Committee and in March 1970 endorsed the computer oriented CAMAC system ${ }^{10}$ as a dataway system complementary to NIM.

\section{Conclusions}

The NIM system has become dominant for nuclear instrumentation in most of the world and has contributed substantially to experimental nuclear physics. The system has the potential for providing to other fields the same advantages that have accrued to nuclear and radiation physics. 
1. Report of National Academy of Sciences National Research Council Advisory Panel 231.00 to Radiation Physics Division of Nat. Bur. Stand., Jan. 26, 1968.

2. U. S. AEC Report TID-20893 (Rev. 3), Standard Nuclear Instrument Modules, Dec. 1969, U. S. Government Printing Office, Washington, D. C. 20402. (Earlier issues are dated July 1964, January 1966 and January 1968).

3. American National Standard Nomenclature and Dimensions for Panel Mounting Racks, Paneis, and Associated Equipment, ANSI C83.9-1968, American National Standards Institute, 1430 Broadway, New York, New York 10018.

4. International Electrotechnical Commission Publication 297, First Edition, 1969, Dimensions of Panels and Racks for Nuclear Electronic Instruments, International Electrotechnical Commission, 1 rue de Varembe, Geneva, Switzerland.

5. J. Bardeen and W. H. Brattain, "Transistor, A. Semi-Conductor Triode," Physical Review, 74, No. 2, 230 (July 15, 1948).

6. United Kingdom Atomic Energy Authority Specification and Guide to the 2000 Series Unitized Equipment, AESS(R) I1048, January 1962, U.K. Atomic Energy Research Establishment, Harwell, Berks, England.

7. CERN 19-inch Chassis Systems, B. Sagnell, CERN Report 62-29, 8 October 1962, European Organization for Nuclear Research, Geneva, Switzerland.

8. ESONE System of Nuclear Electronics, European Atomic Energy Community - EURATOM Report EUR 183ie dated 1964, Office Central De Vente Des Publications, Des Communautes Europeennes, 2, place de Metz, Luxembourg.

9. U. S. AEC Report TID-20893, Standard Nuclear Instrument Modules, July 1964, U. S. Government Printing office, Washington, D. C. 20402 (Superseded by TID-20893 (Rev. 3), December 1969)

10. CAMAC, A Modular Instrumentation System for Data Handling, Description and Specification, EURATOM Report EUR 4l00e dated March 1969, Office Central De Vente Des Publications, Des Communautes Europeennes, 2, place de Metz, Luxembourg. 
REPRESENTATIVES ON AEC COMMITTEE ON NUCLEAR INSTRUMENT MODULES (NIM COMMITTEE)

\begin{tabular}{|c|c|c|c|}
\hline \multirow[b]{2}{*}{ Organization } & \multicolumn{3}{|c|}{ Representatives } \\
\hline & $\begin{array}{c}\text { Initial Committee } \\
\text { (March 1964) }\end{array}$ & $\begin{array}{c}\text { Present Committee } \\
\text { (August 1970) }\end{array}$ & Other \\
\hline $\begin{array}{l}\text { National Bureau of } \\
\text { Standards }\end{array}$ & $\begin{array}{c}\text { Louis Costrell } \\
\text { (Chairman) }\end{array}$ & $\begin{array}{l}\text { Louis Costrell } \\
\text { (Chairman) }\end{array}$ & \\
\hline $\begin{array}{l}\text { U. S. Atomic Energy } \\
\text { Commission }\end{array}$ & $\begin{array}{l}\text { H. R. Wasson } \\
\text { (AEC Liaison) } \\
\text { R. I. Darneal (to } 1 / 68 \text { ) }\end{array}$ & $\begin{array}{l}\text { H. R. Wasson } \\
\text { (AEC Liaison) }\end{array}$ & \\
\hline $\begin{array}{l}\text { Argonne National } \\
\text { Laboratory }\end{array}$ & $\begin{array}{l}\text { S. J. Rudnick } \\
\text { M. G. Strauss (to } 3 / 70 \text { ) } \\
\text { T. W. Hoffer (to } 7 / 68 \text { ) }\end{array}$ & $\begin{array}{l}\text { S. J. Rudnick } \\
\text { J. J. Eichholz (from 9/69) } \\
\text { R. J. Pecina (from 9/69) }\end{array}$ & $\begin{array}{l}\text { R. D. DeForest } \\
\text { (Idaho Falls, } \\
9 / 65 \text { to } 11 / 66\end{array}$ \\
\hline $\begin{array}{l}\text { Atomic Energy of } \\
\text { Canada, Ltd. }\end{array}$ & & V. H. Allen (from $11 / 66$ ) & \\
\hline $\begin{array}{l}\text { Battelle Northwest } \\
\text { (Formerly Hanford } \\
\text { Laboratories) }\end{array}$ & W. G. Spear, Jr. & $\begin{array}{l}\text { W. G. Spear, Jr. } \\
\text { R. E. Connally (from 3/68) } \\
\text { Bill E. Dozer (from 9/69) }\end{array}$ & $\begin{array}{l}\text { W. R. Wood } \\
(1 / 66 \text { to } 3 / 68)\end{array}$ \\
\hline $\begin{array}{l}\text { Brookhaven National } \\
\text { Laboratories }\end{array}$ & $\begin{array}{l}\text { S. Rankowitz } \\
\text { I. H. Redmond }\end{array}$ & $\begin{array}{l}\text { S. Rankowitz } \\
\text { I. H. Redmond }\end{array}$ & \\
\hline CERN & & I. Pizer (from $11 / 66$ ) & \\
\hline Columbia University & $\begin{array}{l}\text { V. Guirogossian } \\
\text { J. Hahn }\end{array}$ & $\begin{array}{l}\text { V. Guirogossian } \\
\text { J. Hahn }\end{array}$ & $\begin{array}{l}\text { S. Dhawan } \\
(2 / 65 \text { to } 3 / 68 \text {, } \\
\text { now Yale Rep) }\end{array}$ \\
\hline $\begin{array}{l}\text { Lawrence Radiation } \\
\text { Laboratory, } \\
\text { Berkeley }\end{array}$ & $\begin{array}{l}\text { A. E. Larsh, Jr. } \\
\text { D. A. Mack }\end{array}$ & $\begin{array}{l}\text { A. E. Larsh, Jr. } \\
\text { D. A. Mack } \\
\text { F. Kirsten (from } 3 / 70 \text { ) }\end{array}$ & \\
\hline $\begin{array}{l}\text { Lawrence Radiation } \\
\text { Laboratory, } \\
\text { Livermore }\end{array}$ & $\begin{array}{l}\text { C. A. Van DenHeuvel } \\
\text { (to } 8 / 65 \text { ) }\end{array}$ & $\begin{array}{l}\text { R. C. Kaifer (from 7/65) } \\
\text { G. L. Strahl (from 9/69) }\end{array}$ & \\
\hline $\begin{array}{l}\text { Los Alamos Scien- } \\
\text { tific Laboratory } \\
\end{array}$ & N. A. Lindsay & $\begin{array}{l}\text { N. A. Lindsay } \\
\text { L. R. Biswell (from 9/69) }\end{array}$ & $\begin{array}{l}\text { B. R. Koch } \\
(9 / 66 \text { to } 11 / 66) \\
\end{array}$ \\
\hline $\begin{array}{l}\text { National Accelerator } \\
\text { Laboratory }\end{array}$ & & Cordon Kerns (from 2/70) & $\begin{array}{l}\text { R. E. Daniels } \\
(10 / 68 \text { to } 2 / 70)\end{array}$ \\
\hline $\begin{array}{l}\text { National Aeronautics } \\
\text { and Space Adminis- } \\
\text { tration (GSFC) }\end{array}$ & & $\begin{array}{l}\text { J. H. Trainor (from 2/66) } \\
\text { D. E. Stillwell (from 9/69) }\end{array}$ & $\begin{array}{l}\text { G. H. Ludwig } \\
\text { (to } 2 / 66 \text { ) }\end{array}$ \\
\hline $\begin{array}{l}\text { Oak Ridge National } \\
\text { Laboratory }\end{array}$ & $\begin{array}{l}\text { S. H. Hanauer } \\
\text { (to U.Tenn 4/65) } \\
\text { N. W. Hill } \\
\text { G. A. Holt }\end{array}$ & $\begin{array}{l}\text { N. W. Hill } \\
\text { G. A. Holt } \\
\text { J. W. Woody, Jr. (from 2/68) }\end{array}$ & \\
\hline $\begin{array}{l}\text { Princeton-Pennsyl- } \\
\text { vania Accelerator }\end{array}$ & & (Appointment pending) & $\begin{array}{l}\text { T. F. Droege } \\
(1 / 65 \text { to } 3 / 70) \\
\end{array}$ \\
\hline $\begin{array}{l}\text { Stanford Linear } \\
\text { Accelerator }\end{array}$ & & $\begin{array}{l}\text { R. S. Larsen (from 11/66) } \\
\text { D. Horelick (from 9/69) }\end{array}$ & $\begin{array}{l}\text { G. Temmes } \\
(11 / 64 \text { to } 8 / 65) \\
\text { V. L. Smith } \\
(8 / 65 \text { to } 11 / 66) \\
\text { W. B. Pierce } \\
(8 / 65 \text { to } 11 / 66)\end{array}$ \\
\hline $\begin{array}{l}\text { University of } \\
\text { Tennessee }\end{array}$ & & & $\begin{array}{l}\text { S. H. Hanauer } \\
(4 / 65 \text { to } 3 / 70) \\
\end{array}$ \\
\hline $\begin{array}{l}\text { U. S. AEC Health \& } \\
\text { Safety Laboratory }\end{array}$ & N. Latner & $\begin{array}{l}\text { N. Latner } \\
\text { V. C. Negro (from 9/69) }\end{array}$ & \\
\hline Yale University & & $\begin{array}{l}\text { C. E. L.Gingell (from 2/68) } \\
\text { S. Dhawan (from } 3 / 68 \text { ) }\end{array}$ & \\
\hline
\end{tabular}


Latest developments in the subject area of this publication, as well as in other areas where the National Bureau of Standards is active, are reported in the NBS Technical News Bulletin. See following page. 


\section{HOW TO KEEP ABREAST OF NBS ACTIVITIES}

Your purchase of this publication indicates an interest in the research, development, technology, or service activities of the National Bureau of Standards.

The best source of current awareness in your specific area, as well as in other NBS programs of possible interest, is the TECHNICAL NEWS BULLETIN, a monthly magazine designed for engineers, chemists, physicists, research and product development managers, librarians, and company executives.

If you do not now receive the TECHNICAL NEWS BULLETIN and would like to subscribe, and/or to review some recent issues, please fill out and return the form below.

Mail to: Office of Technical Information and Publications National Bureau of Standards

Washington, D. C. 20234

Name

Affiliation

Address

City State Zip

Please send complimentary past issues of the Technical News Bulletin.

Please enter my 1-yr subscription. Enclosed is my check or money order for $\$ 3.00$ (additional $\$ 1.00$ for foreign mailing). Check is made payable to: SUPERINTENDENT OF DOCUMENTS. 


\section{PERIODICALS}

JOURNAL OF RESEARCH reports National Bureau of Standards research and development in phvsics, mathematics, chemistry, and engineering. Comprehensive scientific papers give complete details of the work, including laboratory data, experimental procedures, and theoretical and mathematical analyses. Illustrated with photographs, drawings, and charts.

Published in three sections, available se parately:

\section{- Physics and Chemistry}

Papers of interest primarily to scientists working in these fields. This section covers a broad range of physical and chemical research, with major emphasis on standards of physical measurement, fundamental constants, and properties of matter. Issued six times a year. Annual subscription: Domestic, $\$ 9.50$; foreign, $\$ 11.75^{*}$

\section{- Mathematical Sciences}

Studies and compilations designed mainly for the mathematician and theoretical physicist. Topics in mathematical statistics, theory of experiment design, numerical analysis, theoretical physics and chemistry, logical design and programming of computers and computer systems. Short numerical tables. Issued quarterly. Annual subscription: Domestic, $\$ 5.00$; foreign, $\$ 6.25 *$.

\section{- Engineering and Instrumentation}

Reporting results of interest chiefly to the engineer and the applied scientist. This section includes many of the new developments in instrumentation resulting from the Bureau's work in physical measurement, data processing, and development of test methods. It will also cover some of the work in acoustics, applied mechanics, building research, and cryogenic engineering. Issued quarterly. Annual subscription: Domestic, $\$ 5.00$; foreign, $\$ 6.25 *$.

\section{TECHNICAL NEWS BULLETIN}

The best single source of information concerning the Bureau's research, developmental, cooperative and publication activities, this monthly publication is designed for the industry-oriented individual whose daily work involves intimate contact with science and technology-for engineers, chemists, physicists, research managers, product-development managers, and company executives. Annual subscription: Domestic, $\$ 3.00$; for eign, $\$ 4.00 *$.

- Difference in price is due to extra cost of foreign mailing.

\section{NONPERIODICALS}

Applied Mathematics Series. Mathematical tables, manuals, and studies.

Building Science Series. Research results, test methods, and performance criteria of building materials, components, systems, and structures.

Handbooks. Recommended codes of engineering and industrial practice (including safety codes) developed in cooperation with interested industries, professional organizations, and regulatory bodies.

Special Publications. Proceedings of NBS conferences, bibliographies, annual reports, wall charts, pamphlets, etc.

Monographs. Major contributions to the technical literature on various subjects related to the Bureau's scientific and technical activities.

National Standard Reference Data Series. NSRDS provides quantitative data on the physical and chemical properties of materials, compiled from the world's litcrature and critically evaluated.

Product Standards. Provide requirements for sizes, types, quality and methods for testing various industrial products. These standards are developed cooperatively with interested Government and industry groups and provide the basis for common understanding of product characteristics for both buyers and sellers. Their use is voluntary.

Technical Notes. This series consists of communications and reports (covering both other agency and NBS-sponsored work) of limited or transitory interest.

Federal Information Processing Standards Publications. This series is the official publication within the Federal Government for information on standards adopted and promulgated under the Public Law 89-306, and Bureau of the Budget Circular A-86 entitled, Standardization of Data Elements and Codes in Data Systems.
Order NBS publications from:
Superintendent of Documents Government Printing Office Washington, D.C. 20402 
U.S. DEPARTMENT OF COMMERCE

WASHINGTON, D.C. 20230

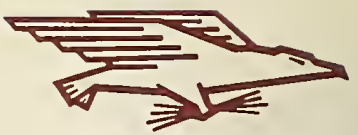

OFFICIAL BUSINESS 